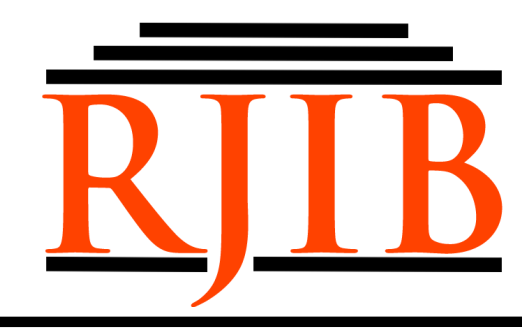

RETORIKA: Jurnal Ilmu Bahasa

Vol. 6, No. 1 April 2020, Page 57-62

\title{
Teaching Procedural Texts: An Eco-Linguistics Perspective
}

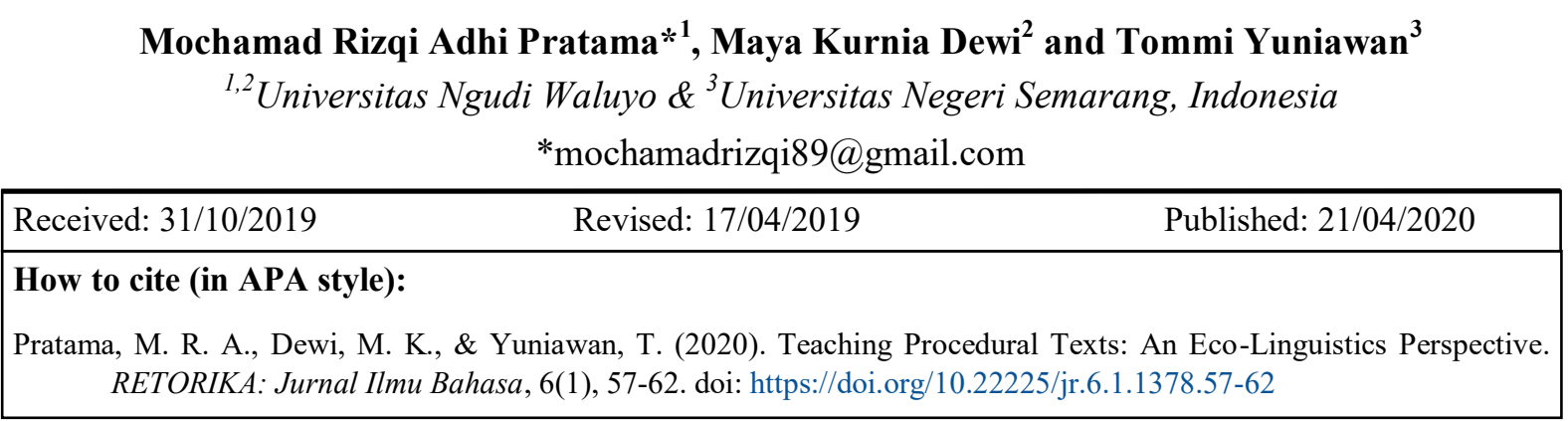

\begin{abstract}
The Curriculum 2013 expects the students to possess both academic achievement and noble characters. Environmental awareness is one of noble characters proposed by The Curriculum 2013 that relates to the eco-linguistics as an interdisciplinary science which involves ecology and linguistics. The objective of this study is to examine the effectiveness of teaching text in the light of eco-linguistics perspective to teach procedural text and recycling garbage. This study employed a mixed method research design. The quantitative method (one group pretest-posttest design of pre-experimental research) is concerned with the improvement assessment of writing procedural text while the qualitative one (questionnaire) was dealt with the investigation of students' knowledge and response about recycling garbage. The research subjects were one class of Junior High School consisting of 32 students taken by purposing sampling. A scoring system of assessing writing proposed by The Curriculum 2013 was used in this study. While the instrument to assess the students' knowledge and response to recycling garbage, a closed question type of questionnaire was applied. The results showed that there is a significant improvement in students writing from 76,72 (pre-test) to 80,47 (post-test). The results of questionnaire also revealed that the students positively respond to the conducted teaching and they have learnt recycling garbage.
\end{abstract}

Keywords: Procedural Text, Eco linguistics, The Curriculum 2013

\section{INTRODUCTION}

Approximately over the past ten years, there have been two developments in language description especially on genre of texts. One of the most well-known notions was proposed by (Howatt \& Widdowson, 2004). Moreover, the notion of focusing on genres in various areas has been convincingly demonstrated by scholars such as (Bhatia, 1991; Hyland, 2003; Hyland \& Hyland, 2006; Paltridge, 2001; Swales, 1990). This shows that genres have become fruitful sources in English Language Teaching and linguistics research.

The Development of The Curriculum 2013 is a further step development of Competency-Based Curriculum which was initiated in 2004 and Unit Level Curriculum in
2006 including to the competency attitudes, knowledge, and skills as integrated form. The development of 2013 curriculum is from the previous one based on four main pillars of the arrangement patterns of thought and governance, the deepening and expansion of the material, the strengthening of the process, and the adjustment burden.

The Curriculum 2013 is designed to meet the needs of society in this era that includes social, moral, religious morals, skills and knowledge. Learning activities to implement the curriculum 2013 is expected to form students who are not only good in academics but also good regarding morale. Therefore, the curriculum 2013 mandates that all subjects should be contributed to the knowledge, skill, and formation of attitude. 
Seen from the field of research, this study is concerned with ELT and Linguistic study. The ELT filed is concerned with the improvement of students' skills in writing procedural text. Linguistics is a scientific research on language phenomena seen both from the perspective of micro and macro (Kentjono, 1982; Kridalaksana, 1984). In this study, linguistics was related to green speak. Green speak is defined as environmental text with all its forms (oral text, written text, picture, and internet) (Fill \& Muhlhausler, 2001).

Procedural text is considered as one of the simplest and easiest text genres in Junior High School. Procedural text is relatively clear without modality nor dependence on view points, etc. and have many potential applications (Maeta, Sasada, \& Mori, 2015). This makes procedural text become applicable for any modification and adjustment.

Procedural text is designed to describe how something is accomplished through a sequence of acts or steps (Derewianka, 1990). Additionally, he also explains that the generic structure of the text of the procedure consists of objectives, tools and materials, and steps (Derewianka, 1990). According to (Gerot \& Wignell, 1994), the text of the procedure is the text used to describe how something is done through a sequence of steps. Additionally, (Anderson \& Anderson, 1997) procedural text as a text which gives information about how and steps of doing something.

Besides, ecolinguistics is an interdisciplinary science integrating language with linguistic ecology. Ecology is defined as a science that studies the interrelationship between humans and nature in the vicinity. Linguistics is the scientific study of the phenomenon of language both in micro and macro (Kentjono, 1982; Kridalaksana, 1984). In other words, eco linguistics examine not only the mutual relationship between man and man which in this case is the interaction between members guyub speech (speech community) who have diverse languages but also examines the interrelationship between humans and the natural surroundings.

This research needs to be done inasmuch as the practice of teaching in Junior High School is still considered not optimal. This notion was confirmed by (Sari, 2016) who conducted an observation on the teaching and learning process in International Standard Schools of Junior High School in Semarang which were still not optimal. Additioanlly, in the present study, the teaching of reading and writing is integrated in two cycles of genrebased approach. It means that in the end of the lesson, the students are able to write procedural text based on what they have read. (Maharani, 2017) argued that one of the skills that forces students extra energy to master it is writing. Moreover, (McCutchen, 2011) stated that writing is the skill which has the highest complexity to master. Hence, the urgency of improving teaching writing is considerably essential.

\section{Table 1}

The difference between eco linguistics-based procedural text and other common procedural texts taught in class

\begin{tabular}{|c|c|c|}
\hline & $\begin{array}{l}\text { Ecolinguistic-Based } \\
\text { Procedural Text }\end{array}$ & $\begin{array}{l}\text { Other Ordinary } \\
\text { Procedural Texts }\end{array}$ \\
\hline Content & $\begin{array}{l}\text { The text is taught to } \\
\text { have a noble } \\
\text { character of love } \\
\text { and care for the } \\
\text { environment. As an } \\
\text { example, the effort } \\
\text { to love the } \\
\text { environment in the } \\
\text { form of recycling } \\
\text { used glass bottle to } \\
\text { make flower vas } \\
\text { and plastic bags to } \\
\text { make flowers. }\end{array}$ & $\begin{array}{l}\text { Text did not teach a } \\
\text { character (moral } \\
\text { knowing). As an } \\
\text { example, } \\
\text { procedural text that } \\
\text { teaches how to } \\
\text { make instant } \\
\text { noodles. }\end{array}$ \\
\hline Activity & $\begin{array}{l}\text { Besides the } \\
\text { students learn } \\
\text { concepts procedure } \\
\text { text in English, } \\
\text { students also } \\
\text { practice how to } \\
\text { love environment. } \\
\text { For example, all of } \\
\text { the students } \\
\text { together with } \\
\text { teachers practiced } \\
\text { how to make flower } \\
\text { vas from used glass } \\
\text { bottle. }\end{array}$ & $\begin{array}{l}\text { Students only learn } \\
\text { the concept of the } \\
\text { procedural text in } \\
\text { English with } \\
\text { teaching conducted } \\
\text { by the teacher and } \\
\text { learn how to do or } \\
\text { make something in } \\
\text { which there is no } \\
\text { character education. } \\
\text { As an example that } \\
\text { students learn how } \\
\text { to make instant } \\
\text { noodles. }\end{array}$ \\
\hline $\begin{array}{l}\text { Teaching } \\
\text { Strategy }\end{array}$ & $\begin{array}{l}\text { In addition, to teach } \\
\text { procedural text in } \\
\text { the English } \\
\text { Language } \\
\text { Teaching, teachers } \\
\text { convey the } \\
\text { importance of } \\
\text { loving and caring } \\
\text { for } \\
\text { environment. the } \\
\text { Teachers always } \\
\text { encourage students } \\
\text { to love the } \\
\text { environment with } \\
\text { activities contained } \\
\text { in the eco } \\
\text { linguistics-based } \\
\text { procedural text. }\end{array}$ & $\begin{array}{l}\text { Teachers only teach } \\
\text { the concept of } \\
\text { procedural text } \\
\text { involving activities } \\
\text { such as making } \\
\text { instant noodles, } \\
\text { making a cup of } \\
\text { coffee, and other } \\
\text { activities. There are } \\
\text { no moral values that } \\
\text { can be taught to } \\
\text { students. }\end{array}$ \\
\hline
\end{tabular}

Curriculum 2013 recommends the use of a scientific approach and the use of text approach in learning English. In the process of 
learning, there are three phases, namely prestage of learning, implementation, and postlearning phase (Iskandarwasid, 2007).

This kind of procedural text has the same characteristics with other genres in their teachings. Genre-based approach as one of the most fashionable text teaching becomes the core of the implementation. Moreover, the presence of genre-based also support the relationship between language and it's function in social settings (Sayukti \& Kurniawan, 2018) Genre-based approach is suitable for both ESL and EFL context (Abbaszadeh, 2013). Moreover, (Campbell \& Green, 2006) also argued that genre-based approach is suitable for both text writing and academic writing.

Five main stages of teaching and learning procedural text has been proposed by (Hammond, Burns, Joyce, Brosnan, \& Gerot, 1992). To implement the genre-based syllabus, (Abbaszadeh, 2013; Hammond et al., 1992) proposed a model presented in Figure 1. The Model includes two cycles and four stages:

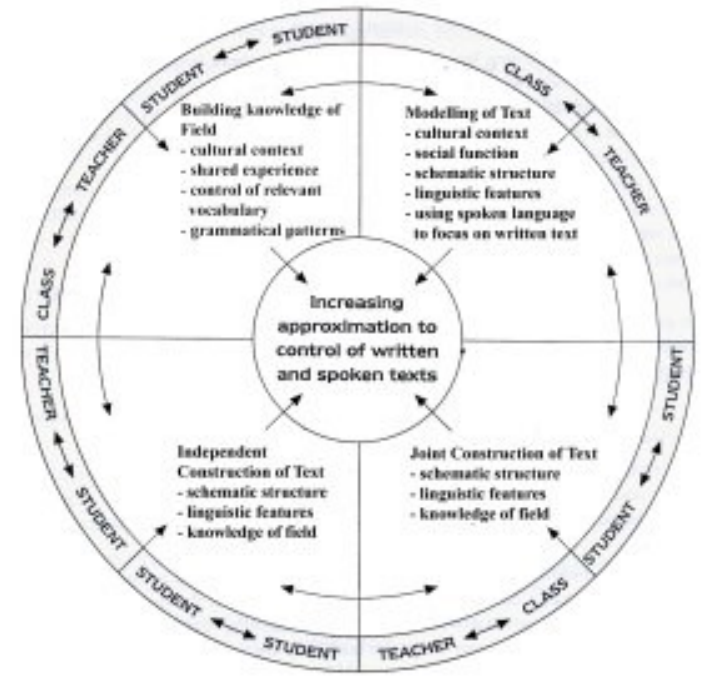

Figure 1

Model of Genre-Based Approach

The first stage of the cycle is called Building Knowledge of the Field (BKOF) in which the teachers and students established cultural context, share experiences, discuss vocabulary, grammatical patterns, and so on. All of these were discussed around the types of spoken text and topics they are going to deal with at the second stage. The second stage is called Modeling of Text (MOT), in which the students listen to statements of short functional texts, conversation, and monologues which are established around a certain communicative purpose. For instance, if students are expected to produce procedural texts, then the short functional texts, conversation, and the monologues are developed with one main communicative purpose. In short, at the second stage, students listen and respond to various texts with similar communicative purpose.

After listening, the students come into the third stage called Joint Construction of Text (JCT). At this stage, they try to develop spoken text with their peers, with help from the teachers. They can create different announcements, conversations, on showing how to do things, monologue on how to make something, and so on. They need to demonstrate their speaking ability to show confidence to speak.

After having experience of collaborating with friends, they come into the fourth staged called Independent Construction of Text (ICT). In this stage, students are expected to be able to speak spontaneously or make monologues aimed at giving directions or showing ways to do things such as how to make kite, how to make a paper cap, and so on. Thus, the first cycle integrates the development of speaking and listening skills.

In the development of written procedural text, the steps are simply the same. However, the students write what they have read. In other words, the teachers and students are geared in the integration of the development between reading and writing. The activity of recycling garbage can be done in the stage of Modelling of Text. While the teacher is presenting how procedural text is, the teacher can lead the students to practice the steps. The students can be asked to prepare the materials and equipment to do the procedures. Hence, in the end of the teaching, students have learnt the procedural text and have their own recycling products.

\section{Pre-Teaching}

At this stage, teachers ask the students to bring the materials and equipment to do the procedures. One example of the character of environmental awareness is recycling waste. The procedural text entitled "How to make flower vas from the used bottle?" That will be used as a model of text analysis for its structure by students.

\section{Steps of Implementation}

Ecolinguistics-based procedural text learning implemented by the approaches, methods, and techniques as follows:

\section{Approach}

The approach used is constructivist approach so that the character concerned about 
the environment can be embedded in students.

2. Method

Curriculum 2013 recommends using methods of Project-Based Learning or Problem -Based Learning. Ecolinguistic-based procedural text is structured with a model of project-based learning so that students, at the end of learning, have a product or activity as a result of the implementation of the learning they receive.

3. Technique

The dominant learning technique in this program is the focus group discussions and presentations. The group discussion occurred when students go through a stage Joint Construction of Text. At this stage, it is expected that students can share their knowledge and understanding gained from the previous stage. The presentation will take place when students deliver the procedures they had made in front of the class. This stage has become the aspects of speaking.

\section{Post-Teaching and Learning Process}

After the teacher teaches eco linguisticsbased procedural text, teachers monitored students' progress and alert students to recycle waste and asked what activities they have done that reflects the value of loving environment. At the end of the lesson, each group had products of recycling garbage in the forms of flower vas from used glass bottles and flowers from plastic bags. The products can be used directly in the school as well as potted plants and can also be exhibited to a wide audience as a form of cultural promotion of recycling as well as invite people to cultivate the principle of recycling to save the environment from the waste. Media to show off can be procurement exhibition or publication on the web schools so that what has been done by the students in the school can be emulated by other schools throughout Indonesia. As business development, a product of students' work can also be contested between the students, class, and school provincial or national level in an effort to the promotion of a culture of national waste recycling through school education.

Based on background above, The research aims to answer the following research problems, there are; Is Teaching Procedural Text: An Eco linguistic Perspective effective to improve students' skill of writing procedural text? And Is Teaching Procedural Text: An Eco linguistic Perspective effective to improve students' knowledge of recycling garbage?

\section{METHOD}

This research is used a mixed method. The quantitive data employed one group pretest -posttest design of pre-experimental research and were in the form of pre-test and post-test mean score. The qualitative one was concerned with the students' knowledge and response to recycling garbage taken by questionnaire.

\section{Participants}

Table 2

Sample Size on Purposive Sampling Technique

\begin{tabular}{cccc}
\hline & \multicolumn{3}{c}{ Number of Samples } \\
& Gender & Number & Total \\
\hline \multirow{2}{*}{ Sample } & $\begin{array}{c}\text { Female } \\
\text { Male }\end{array}$ & 18 & 32 \\
& Mal & 32 \\
\hline
\end{tabular}

As illustrated in Table 1, the participants consist of a representative sample of 32 ninth graders of junior high school. The samples were decided according to purposive sampling method (Bryman, 2016; Creswell \& Guetterman, 2019). The samples were purposively assigned into a group with sample size of 32 participants. The entire participants possessed relatively similar cultural and ethnic background and the same mother tongue that is Javanese. This information was verified through the questionnaires distributed in the beginning of the study.

\section{Tested Items}

The selection of problems is based on the learning outcomes of teaching procedural text and environmental awareness proposed in the 2013 Curriculum. The skill of writing procedural text is assessed through the students' product of writing procedural text. Hence, the students' writings were assessed by using a rubric proposed by the 2013 curriculum. The knowledge about recycling is assessed through questionnaire investiganting the students' response to Recycling garbage. The questionnaire employed closed statement with options (agree, quite agree, less agree, disagree).

\section{Measures \& Instrument Validation}

In purpose to obtain the valid score of students' writing skill of procedural text, the proper assessing instruments were required. A scoring system of assessing writing proposed by The Curriculum 2013 was used in this study. While the instrument to assess the students' knowledge and response to recycling garbage, a closed question type of questionnaire was applied. The questionnaire has been validated by an ecolinguistic expert, Dr. Tommi Yuniawan, M. Hum. from 
Universitas Negeri Semarang.

\section{RESULTS AND DISCUSSION}

\section{Effects of The Teaching on Students' Knowledge and Skills}

Pre-Test and Post-Test

In order to ascertain the significant difference between the pre-test and post-test, a calculation of students' mean scores in writing procedural text was conducted. The following figure ilustrate the improvement of students' means scores.

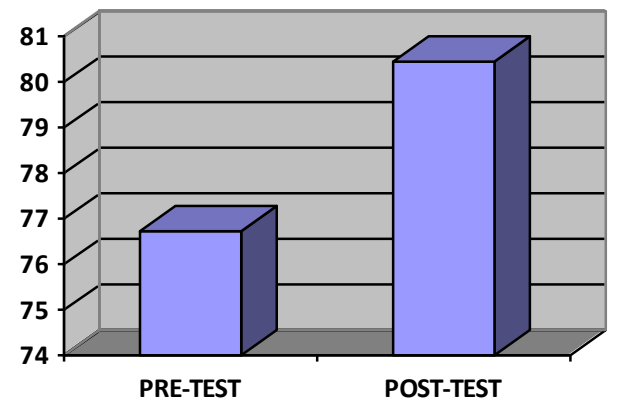

Figure 2

The mean of pre-test and post-test

The mean score of pre-test showed 76,72 while the mean score of post-test showed 80,47 . It has proven that the conducted teaching is able to improve students' skill of writing procedural text.

\section{Questionnaire}

The results of questionnaire showed that the majority of students positively respond to the closed statement. The students felt that they have learnt new knowledge about recycling garbage. Based on the answers given by the students, most of them answers 'agree' and 'quite agree' with the closed statement.

\section{Educational Implication}

Based on the guidelines of the 2013 curriculum, all subjects should contribute to the instilling process of attitude, skill, and knowledge. In teaching and learning process of the eco linguistic-based procedural text, students do not only learn procedural text but also noble values in the form of loving environment through recycling garbage. Students learn how to recycle garbage to make a more useful thing to reduce garbage. In this case, the students learn how to make vas from used glass bottle and flowers from plastic bags.

In the practice of teaching and learning procedural texts, the activity of recycling garbage can be replaced with other activities such as making flower pot from used plastic mineral water, mini monument from ice cream stick, and so on. In the end of the teaching and learning process of eco linguistic-based procedural text, the learners also have their own creative products in the form useful things from recycled garbage.

\section{CONCLUSION}

Based on the research results, it can be concluded that teaching Procedural Text as an Eco linguistic Perspective is effective to improve students' skill of writing procedural text from 76,72 (pre-test) to 80,47 (post-test). Besides that, teaching Procedural Text as an Eco linguistic Perspective is effective to improve students' knowledge of recycling garbage.

\section{REFERENCE}

Abbaszadeh, Z. (2013). Genre-based approach and second language syllabus design. ProcediaSocial and Behavioral Sciences, 84, 18791884. Retrieved from https://core.ac.uk/ download/pdf/82309341.pdf

Anderson, M., \& Anderson, K. (1997). Text Types in English. South Melbourne: Macmillan Education. Retrieved from https:// trove.nla.gov.au/work/8428269? q\&sort=holdings + desc\&_=1586916528067 \&versionId $=29283975$

Bhatia, V. K. (1991). A genre-based approach to ESP materials. World Englishes, 10(2), 153166. Retrieved from https:// www.researchgate.net/ publication/227769195_A_genrebased_approach_to_ESP_materials

Bryman, A. (2016). Social Research Methods (5th ed.). Oxford: Oxford University Press.

Campbell, R., \& Green, D. (2006). Literacies and learners. Current perspectives. (3rd ed.). New South Wales: Pearson Education Limited. Retrieved from https:// catalogue.nla.gov.au/Record/3601533

Creswell, J. W., \& Guetterman, T. C. (2019). Educational Research: Planning, Conducting, and Evaluating Quantitative and Qualitative Research, 6th Edition. Upper Saddle River: Pearson Prentice Hall. Retrieved from https://eric.ed.gov/? $\mathrm{id}=$ ED594549

Derewianka, B. (1990). Exploring how texts work. Rozelle. New South Wales: Primary English Teaching Association. Retrieved from https://catalogue.nla.gov.au/Record/1757085 
Fill, A., \& Muhlhausler, P. (2001). The Ecolinguistics Reader Language, Ecology, and Environment. London: Continuum. Retrieved from https://epdf.pub/theecolinguistics-reader-language-ecology-andenvironment.html

Gerot, L., \& Wignell, P. (1994). Making sense of functional grammar: An introductory workbook. Queensland: Antipodean Educational Enterprises. Retrieved from https://www.goodreads.com/book/ show/9815147-making-sense-of-functionalgrammar-an-introductory-workbook

Hammond, J., Burns, A., Joyce, H., Brosnan, D., \& Gerot, L. (1992). English for specific purposes: A handbook for teachers of adult literacy. Sydney: National Centre for English Language Teaching and Research. Retrieved from Record/2615149

Howatt, A. P. R., \& Widdowson, H. G. (2004). A History of ELT, Second Edition. Oxford: Oxford University Press. Retrieved from https://books.google.co.id/books/about/ A_History_of_ELT_Second_Edition.html? $\mathrm{id}=\mathrm{g} 2 \mathrm{e} 7 \mathrm{iw} \_\mathrm{F}-\bar{Z} \mathrm{cC} \& \overline{\mathrm{r}}$ edir_esc $=\mathrm{y}$

Hyland, K. (2003). Genre-based pedagogies: A social response to process. Journal of Second Language Writing, 12(1), 17-29. Retrieved from https://doi.org/10.1016/S1060-3743(02) 00124-8

Hyland, K., \& Hyland, F. (2006). Contexts and issues in feedback on L2 writing: An introduction. Cambridge: Cambridge University Press. Retrieved from https:// www.researchgate.net/ publication/285659628_Contexts_and issues in_feedback_on_L2_writing_An_introducti on

Iskandarwasid. (2007). Strategi Pembelajaran Bahasa. Bandung: Rineka Cipta.

Kentjono, D. (1982). Dasar-dasar Linguistik. Jakarta: Fakultas Sastra Universitas Indonesia.

Kridalaksana, H. (1984). Kamus Linguistik. Edisi kedua. Jakarta: Gramedia Pustaka Utama.

Maeta, H., Sasada, T., \& Mori, S. (2015). A Framework for Procedural Text Understanding. In Proceedings of the 14th International Conference on Parsing Technologies (pp. 50-60). Association for Computational Linguistics. Retrieved from https://www.aclweb.org/anthology/W152206

Maharani, M. M. (2017). The Application Of Indirect Feedback To Improve Students' Paragraph Writing. Edulite: Journal of
English Education, Literature and Culture, 2 (2), 389-404. Retrieved from http:// dx.doi.org/10.30659/e.2.2.389-404

McCutchen, D. (2011). From novice to expert:Implications of language skills and writing-relevant knowledge for memory during the development of writing skill. Journal of Writing Research, 3(1), 51-68. Retrieved from http://dx.doi.org/10.17239/ jowr-2011.03.01.3

Paltridge, B. (2001). Genre and the Language Learning Classroom. Michigan, United States of America: Michigan Publishing. Retrieved from https:// www.press.umich.edu/23749

Sari, H. I. (2016). Errors In Using English As Classroom Language Committed By The Ict Teacher Of Smp Negeri 2 Semarang. Edulite: Journal of English Education, Literature and Culture, 1(1), 41-56. Retrieved from http://dx.doi.org/10.30659/ e.1.1.41-56

Sayukti, N. K. H., \& Kurniawan, E. (2018). An Analysis of Student's Recount Text in Systemic Functional Linguistic Perspectives. RETORIKA: Jurnal Ilmu Bahasa, 4(1), 5359. Retrieved from https://doi.org/10.22225/ jr.4.1.466.53-59

Swales, J. M. (1990). Genre analysis: English in academic and research settings. Cambridge: Cambridge University Press. Retrieved from https://doi.org/10.1075/z.184.513swa 